\title{
Two Classic Maya ballplayer panels from Tipan Chen Uitz, Belize
}

Christopher R. Andres ${ }^{1, *}$, Christophe Helmke ${ }^{2}$, Shawn G. Morton ${ }^{3}$ $\&$ Gabriel D. Wrobel ${ }^{1}$

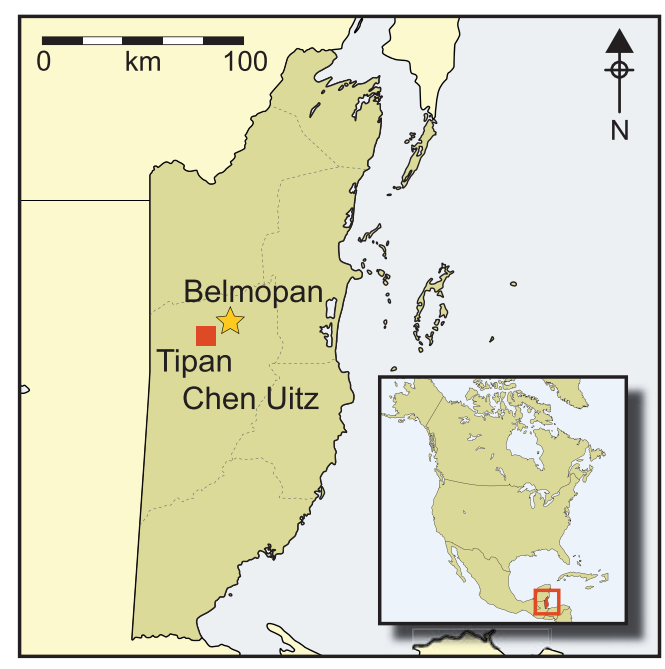

Recent archaeological investigations at Tipan Chen Uitz, Belize, yielded two remarkable Classic Maya ballplayer panels. Iconographic and glyphic analysis of these panels within a regional context provides new insights into large-scale socio-political relationships, demonstrating that the ballgame was an important means and mechanism for macropolitical affiliation in the Maya Lowlands. The panels suggest that Tipan was part of a wider system of vassalage that tied it to other Maya centres, including Naranjo, a regional capital under the dominion of Calakmul where the Snake-Head dynasty held sway. The data presented here underpin a more general discussion of archaeological approaches to ancient interaction spheres.

Keywords: Belize, Tipan Chen Uitz, Maya, Late Classic, ballgame

\section{Introduction}

An increasing number of archaeological investigations in the Maya area and new breakthroughs in hieroglyphic decipherment have shown that pre-Hispanic Maya centres occupied positions of differing and shifting prominence in complex sociopolitical networks. Evidence for such hierarchical organisation-including relationships of vassalage and dependency — are being identified in the art, architecture and iconography of ancient Maya communities (e.g. Martin \& Grube 2000). This premise can be

1 Department of Anthropology, Michigan State University, 665 Auditorium Road, East Lansing, MI 48824, USA

2 Institute of Cross-Cultural and Regional Studies, University of Copenhagen, Karen Blixens Plads 8, 2300 Copenhagen S, Denmark

3 Department of Anthropology, Northern Arizona University, 5 E. McConnel Drive, Flagstaff, AZ 86011-5200, $U S A$

* Author for correspondence (Email: kipandres@hotmail.com)

(C) Antiquity Publications Ltd, 2017 
examined through a pair of recently discovered ballplayer panels from the Maya centre of Tipan Chen Uitz, Belize. Ultimately, we argue that iconography offers insights into inter-polity relationships, that the ballgame was an important mechanism for macro-political affiliation in the Maya area and that the data from Tipan are useful in considering archaeological approaches to ancient interaction spheres in general.

Since its inception in 2009, the Central Belize Archaeological Survey has pursued a regional approach to studying ancient Maya cultural development in the area between the Caves Branch and Roaring Creek drainages of the Cayo District, Belize (e.g. Andres et al. 2011a; Wrobel et al. 2012, 2013; Morton 2015). This project expands upon the efforts of the Western Belize Regional Cave Project that operated in the Roaring Creek Valley between 1997 and 2001 (e.g. Awe 1998, 1999; Awe \& Helmke 2007; Helmke 2009). Surface sites recorded to date range in size from isolated house mounds, to patiofocused residential clusters, to large conglomerations of monumental architecture that can be classed as first- and second-order central places (Helmke \& Awe 2012; Andres et al. 2014).

Of particular relevance to our research is the civic-ceremonial centre of Tipan Chen Uitz, first documented in 2009 (Andres et al. 2010, 2014). In addition to its large size and architectural complexity, Tipan is distinguished by its physical integration with surrounding minor centres via an extensive network of causeways (or sacbeob) (Figure 1). Tipan's position at the hub of this network provides perhaps the most tangible evidence that the site functioned as the head of a regional polity (Andres et al. 2011b).

Among the most notable discoveries to date have been four hieroglyphic monuments, all recovered on structure A-1 at the entrance to the community's palatial complex. Two of these-monuments 1 and 2-both of which are fragmentary and exhibit incomplete texts, have been discussed elsewhere (Andres et al. 2014; Helmke \& Andres 2015). Here we consider monuments 3 and 4, which were recovered during the 2015 field season. These monuments are both ballplayer panels-the first to be found in Belize-and display short but complete hieroglyphic captions. When considered in combination, these panels confirm that Tipan was the seat of an influential royal court, able to commission well-executed monuments produced by literate scribes. The court actively employed the same symbolic vocabulary in terms of monumental forms and compositions of image and text that was characteristic of the most important Late Classic dynasties.

More significantly still, these ballplayer panels may reflect a greater system of allegiances cemented in part by public performances involving vassals and overlords participating in the ballgame. Thus, our research investigates the premise that Tipan may have been part of this greater system of vassalage, tying it to the Maya centre of Naranjo and thereby-however indirectly-to the Snake-Head dynasty focused at the still larger site of Calakmul. As discussed below, Tipan's interaction with Naranjo may well imply such a relationship, as Naranjo's Late Classic kings offered fealty to their overlords at Calakmul (Martin \& Grube 2000: 74-80, 105-111; Grube 2004; Helmke \& Kettunen 2011).

(C) Antiquity Publications Ltd, 2017 


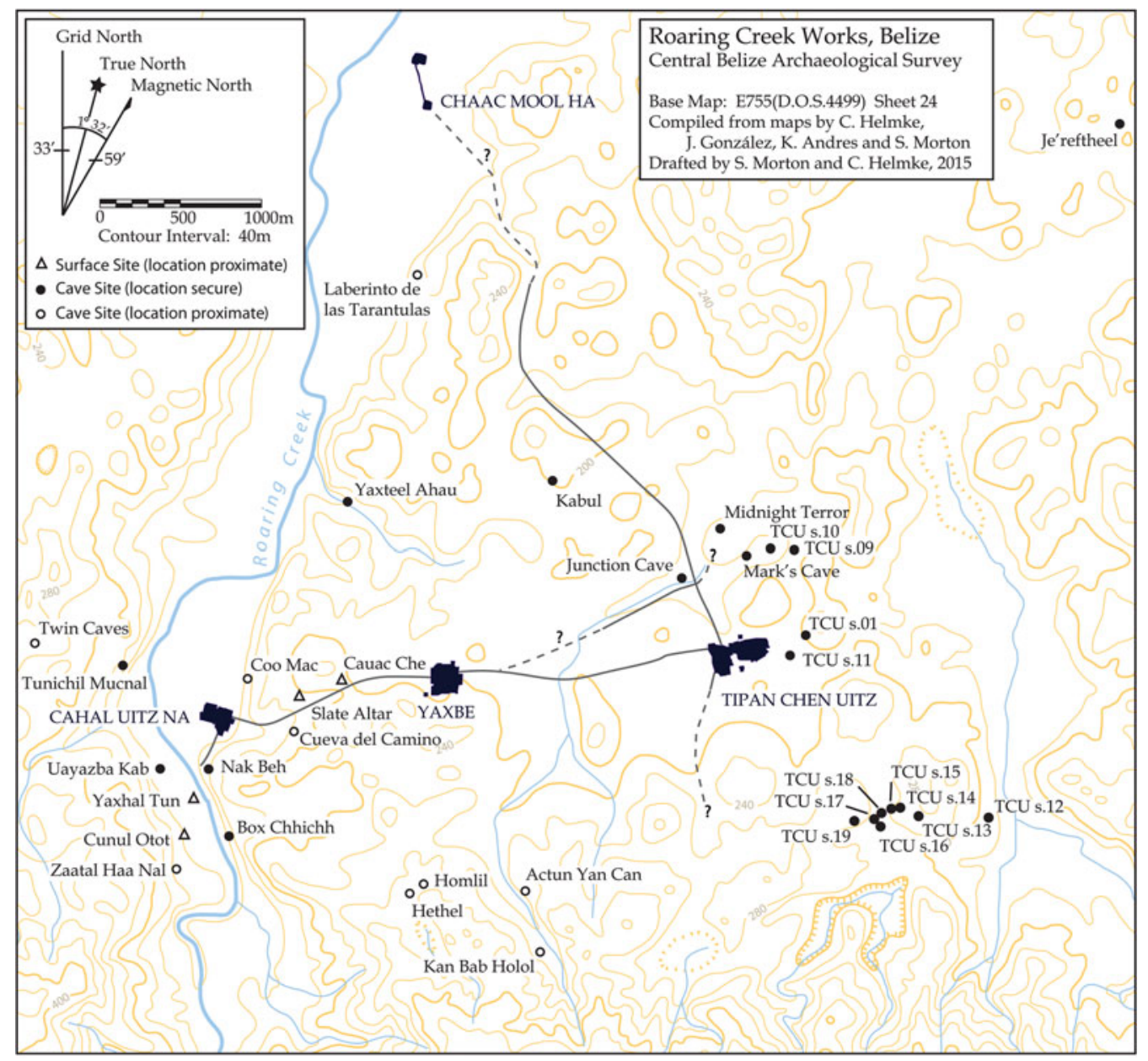

Figure 1. Map of the Roaring Creek Works showing the causeway system integrating Tipan with the secondary centres of Yaxbe and Cahal Uitz Na (map by Shawn G. Morton and Christophe Helmke).

\section{Context of discovery}

Structure A-1 forms the lowest level of acropolis A, and served as the formal entrance to Tipan's paramount palatial complex, via a Passage Range Structure (or audiencia) (Figure 2). The two large fragments of monument 3 were found lying face down on the surface of a secondary platform, just south of a looters' trench in this structure, and on the nearby plaza (Figures $3 \& 4$ ). Monument 4 was discovered face up, on the opposite side of the looters' trench, and had also clearly been displaced in antiquity from its original context; much like monument 3 , it was found resting atop terminal-phase architecture and sealed beneath collapse debris. Fortunately, the illicit excavations passed between the monuments without disturbing either. Exposure of structure A-1's west face revealed a poorly preserved pair of secondary terraces, or lateral stair blocks, constructed over the upper parts of the earlier stairs (see Figures $3 \& 4$ ). In both cases, these architectural units lack facings, and their 


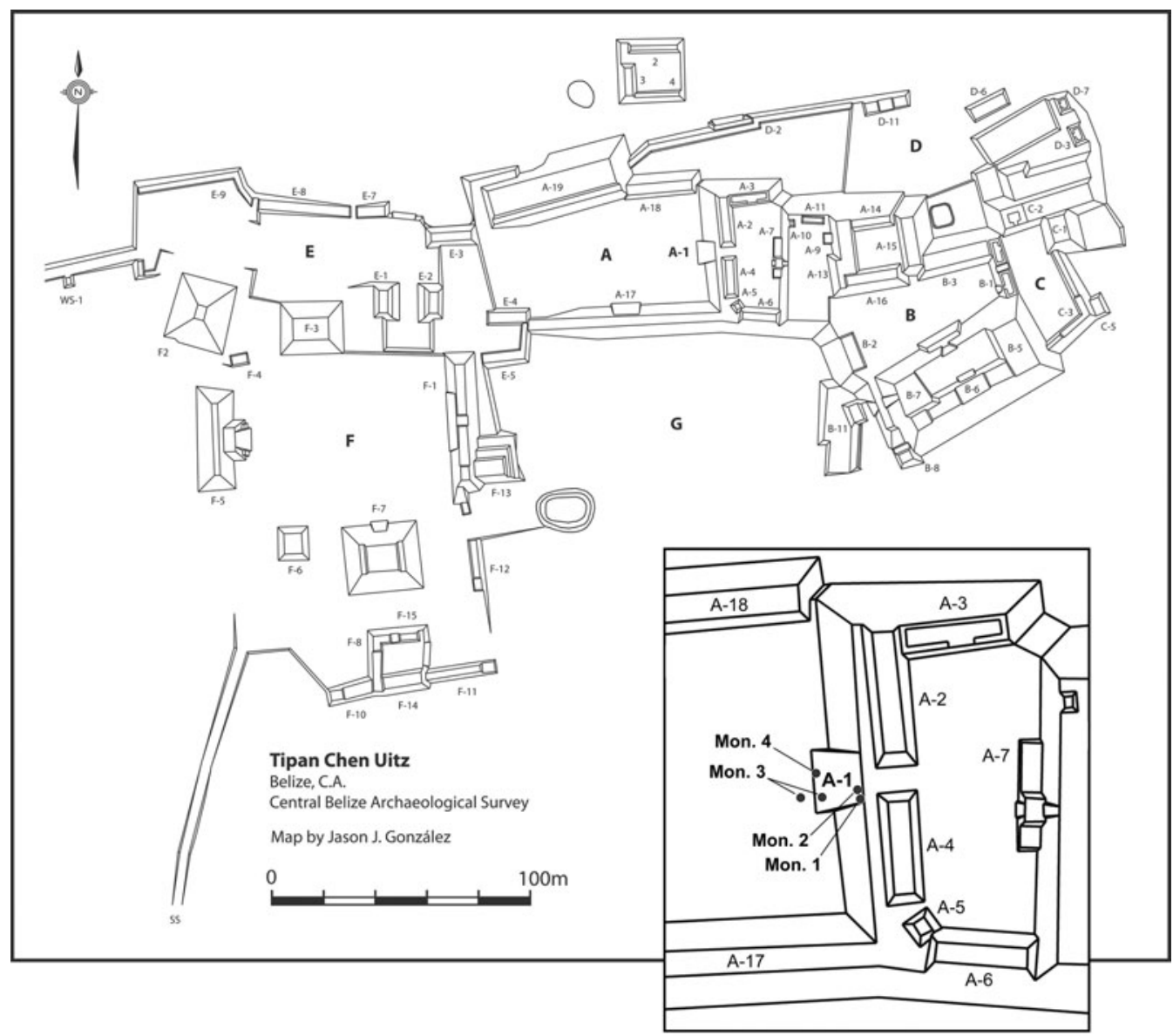

Figure 2. Map of the monumental epicentre of Tipan Chen Uitz showing the location of the community's acropoline palatial complex (acropolis $A$ ) and the location of the monuments discovered on structure A-1 (map by Jason J. González; inset by Christophe Helmke and Christopher R. Andres).

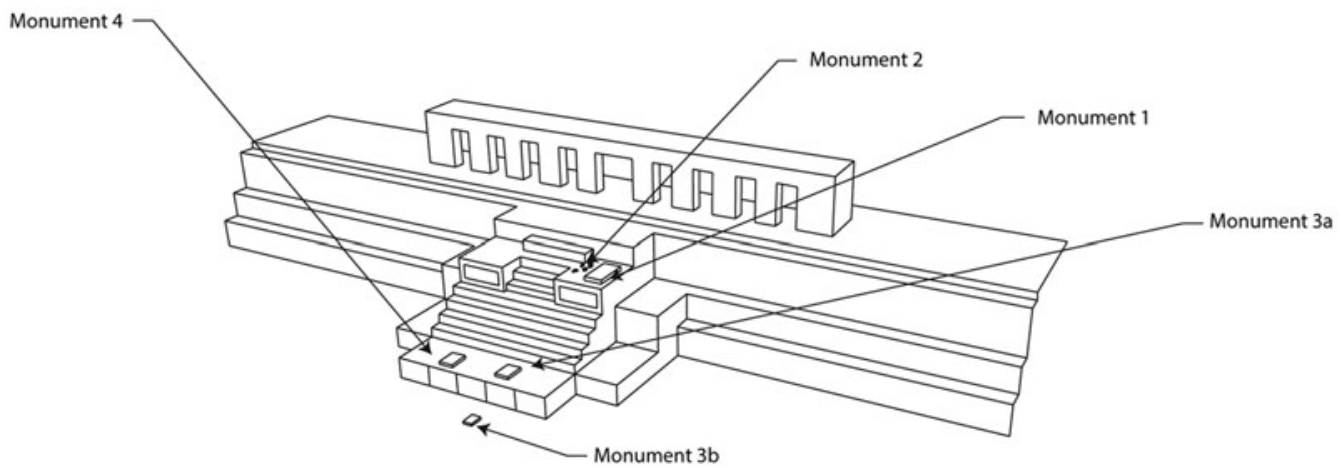

Figure 3. Isometric reconstruction of structure A-1 at Tipan Chen Uitz showing the context of recovery of monuments 1, 2, 3 and 4 (reconstruction by Christopher R. Andres, drafted by Shawn G. Morton).

(C) Antiquity Publications Ltd, 2017 


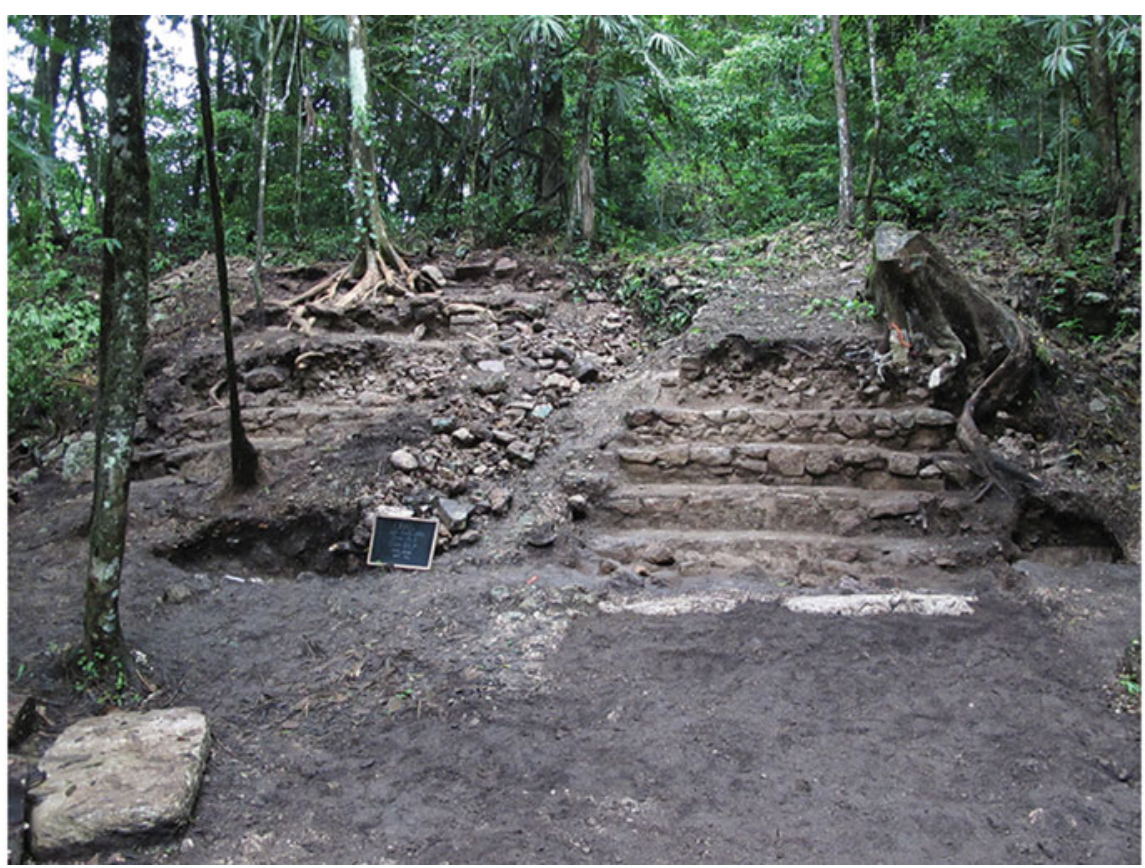

Figure 4. Photograph of structure A-1 showing architectural features exposed during the 2015 excavations (photograph by Christopher R. Andres).

destabilised dry-laid core was collapsing down the building. The available evidence suggests that monuments 3 and 4 were probably integrated into the upper reaches of the building, and may have faced portions of these deteriorated architectural units. The implications of this context are considered below.

\section{Monument 3}

Monument 3 would have measured up to around $1.44 \mathrm{~m}$ wide, $0.66 \mathrm{~m}$ high and approximately $0.2 \mathrm{~m}$ thick when complete (Figure 5); approximately 90 per cent of the original monument is preserved. It is fortunate that the monument and its subtle carvingrendered in low relief, with foreground and background distinguished by no more than $5 \mathrm{~mm}$ and details rendered in shallow $1 \mathrm{~mm}$ lines-suffered only minor damage and moderate weathering. It is unknown if the breakage was accidental, the result of structural collapses or was deliberate. Defacement of the entire carved figure and differential spalling of the panel support the latter interpretation.

That the panel's iconography represents a ballplayer is demonstrated by the individual's pose and distinctive protective belt, and by their juxtaposition with a large circular ball. The panel may depict a ballgame that was celebrated within the ballcourt at Tipan Chen Uitz (Figure 2), or commemorates such a game played at an allied site. Although the figure's garments and headdress are mostly effaced, he holds in his left hand a staff-like object that terminates in a circular element embellished by streamers. Similar examples of this object at sites in the Usumacinta area have been identified as fans (see Houston et al. 2006:

(C) Antiquity Publications Ltd, 2017 

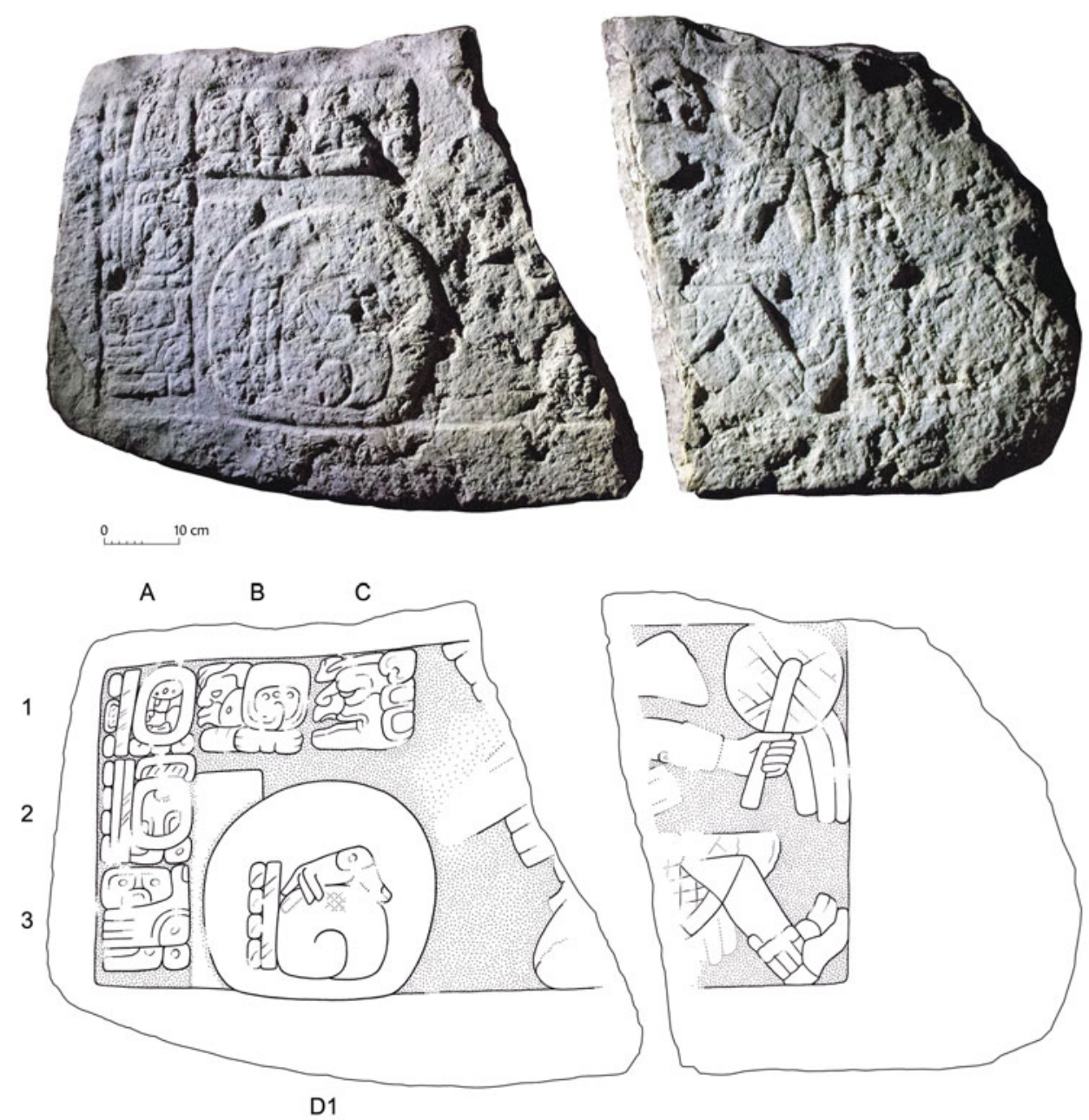

Figure 5. Monument 3, Tipan Chen Uitz, Belize (photograph and drawing by Christophe Helmke).

89-92, figs 5-6). A Late Classic polychrome vase, depicting perhaps the start or the end of a ballgame, includes the bleachers above, wherein figures blow trumpets, while another figure holds precisely the same type of fan (Kerr 1992: 437). This presents an interesting parallel to the iconography of monument 3 .

The ball is captioned by a glyph block of three signs, including the numeral 'nine' and a hand with outstretched fingers that represents the logogram nahb, for 'handspan' (Kevin Johnston pers. comm. to Stephen Houston 1985; Coe 2003; Zender 2004). Below the hand is a large scrolled sign representing a rubber ball that is partially embellished by crosshatching (see Stone \& Zender 2011: 164-65). The whole glyph reads 'nine handspan ball', thereby providing an unusually complete designation for a rubber ball. While this qualifier clearly records a size gradation, it remains unclear whether the handspans refer to the length of the latex strip used to manufacture the ball, or, more probably, to the circumference of a large rubber ball (see Zender 2004; Helmke 2007).

(C) Antiquity Publications Ltd, 2017 
The glyphic text framing the scene is remarkably well preserved and, most unusually, appears to be complete. The clause is headed by a calendrical notation, recording a typical Calendar Round date, the juncture between ritual and the solar calendars (A1A2). Together, these can be translated as '[On the day] 7 Kimi and 14 Sek'. This Calendar Round combination commemorates an historical event on an 'uneven' date, rather than a period-ending celebration on an 'even' date in the Long Count calendar. Anchoring this date to the Long Count is difficult, as this Calendar Round date re-occurs six times in the Late Classic between AD 560 and 820. Nevertheless, the closest possible date to the anchor provided by monument 1 (which commemorates the period-ending of 9.14.0.0.0 or AD 711), is 9.14.4.9.6, or 18 May AD 716 (using a GMT+2 correlation; see Martin $\&$ Skidmore 2012). This is a significant anchor, as dates on particular structures and in discrete areas of sites tend to cluster together. There are, however, additional reasons for preferring this date above the other possibilities, as mentioned below.

The verb is written in a somewhat abridged form as ch'amaw (A3), involving the root ch'am: 'grasp, take'. In other contexts, this verb is usually seen in statements of royal accession, wherein an incumbent ruler takes a sceptre that symbolises the ascent to power and new office (e.g. Schele 1980). As Maya texts are essentially self-referential, commonly naming the very objects upon which they appear, we assume that the 'grasping' here refers to the ballplayer's fan. It is unusual to see such a pairing, not least because we know of no other examples showing a similar pairing of ballplayer and fan. Then again, the verb ch'am is not usually represented on ballplayer panels either, and therefore must have been significant enough to merit a careful mention. It is, therefore, possible that this represents a variant of the game involving a fan, or a heretofore unknown phase of the game.

The last two glyph blocks appear to record the name of the subject-probably the individual represented on the panel. In the first collocation (B1a), the main sign represents an anthropomorphic profile with exaggerated and elongated lips. From examples in texts at Caracol, Copan and Palenque, it would appear to name a particular wind deity, but is used here as an anthroponym (see Stuart 2005: 25, no. 3). The glyph below this main sign is partly eroded and therefore cannot be conclusively identified.

The final glyph block (C1) represents the profile of a feline with a water lily draped above its head. Whereas the literature usually refers to this feline as a "waterlily jaguar" (Schele \& Miller 1986: 51), glyphic captions in other texts clearly show that this is a hix or 'ocelot', another lesser spotted feline (Houston \& Stuart 1989: 6). The qualifying elements preceding the head of the feline (B1b) include the undeciphered waterscroll sign, with its common phonetic complement below. This logogram undoubtedly represents a body of water, or even a wave. Unfortunately, the dictionary entries of lowland Mayan languages are insufficient to provide a plausible decipherment. The combination of a waterscroll sign and an ocelot is a well-attested nominal sequence for a supernatural entity, a spiritual co-essence known as a way or wahy creature (see Houston \& Stuart 1989; Grube \& Nahm 1994: 690; Helmke \& Nielsen 2009; Stone \& Zender 2011). The example provided here is one of the first instances in which this nominal sequence is applied to an historical individual, although a comparable example is known from a text at Copan (Bíró 2010: 24). Accordingly, the individual represented on the panel, in the act of playing ball, may warrant the nickname Waterscroll Ocelot. Unfortunately, the titles that this individual bore are not recorded. This 
in turn implies that the figure was sufficiently well known to the original target audience that this was unwarranted, suggesting that the figure could be the ruler of Tipan. With the discovery of monument 4 , however, it is unclear which, if any, of the individuals represented on these monuments was the local ruler.

\section{Monument 4}

Only the rightmost portion of monument 4 has been recovered, representing up to twothirds of the original panel. It measures approximately $0.56 \mathrm{~m}$ high, $0.205 \mathrm{~m}$ thick and was originally over $0.81 \mathrm{~m}$ wide. Its similarity in size and composition to monument 3 clearly suggests that the two monuments formed part of a set (Figure 6). As with monument 3 , the carving is shallow, ranging between 1 and $6 \mathrm{~mm}$ in depth, and a plain frame encloses the iconographic scene accompanied by a glyphic caption. As panels adorning the face of an architectural unit, these monuments may represent elements of a hieroglyphic stair, although this designation requires more conclusive evidence from future excavation.

Monument 4 also depicts a ballplayer in a dynamic pose: this figure lunges forward and braces his left knee, leaning on his left hand as though attempting to strike a ball. The marked dynamism of the scene is evident in the placement of the knee and the hand, as they burst out of the ground line defined by the lower edge of the frame. The figure wears the large and distinctive ballplayer belt, again composed of three large segments, and is lavishly adorned with regalia. Much of the attire is lost, as the left portion of the scene is eroded and suffered extensively from the breakage of the monument. The area around the face is also quite weathered and may have been deliberately hammered off. Similar damage has been noted on other contemporaneous monuments in the Maya lowlands, such as the stelae of Xunantunich (see Helmke et al. 2010) and panel 3 of Cancuen (Normark 2009).

Fortunately, the right portion of monument 4 suffered only moderate and even weathering suggestive of natural taphonomy. The glyphic caption is composed of five glyph blocks. The first glyph block (A1) is read ubaah, 'it is his portrait' (literally head), the common predicate for captions accompanying iconographic scenes. The following two glyph blocks contain the name of the individual depicted, one Janaab Ti' Chanal K'ahk', or 'bird of prey is the mouth of celestial fire'. Interestingly, a partial glyphic text from a fragmentary ballcourt ring found at Naranjo (see Graham 1980: 187), the nearest supra-regional capital in the area, also records the segment $t i$ ' chanal k'ahk'. This piece of evidence is intriguing because at Tipan this individual is represented as a ballplayer, and at Naranjo, part of the same name appears on a ballcourt ring. It is possible, although by no means certain, that these monuments name the same individual, thus providing a further connection between Tipan and Naranjo (see Andres et al. 2014); in this case, in the explicit context of the ballgame.

The final glyph block (B3) represents the full geometric form of the regal title ajaw, while the preceding block (B2) is read nahho'chan, for 'first five skies' or perhaps 'great five skies'. This segment provides the name of a supernatural location that is known from the textual corpus as the celestial abode for a range of deities, or as a title of particular patron deities (Schele \& Miller 1986: 52; Stuart \& Houston 1994: 71). Nevertheless, it is rarely used as

(C) Antiquity Publications Ltd, 2017 

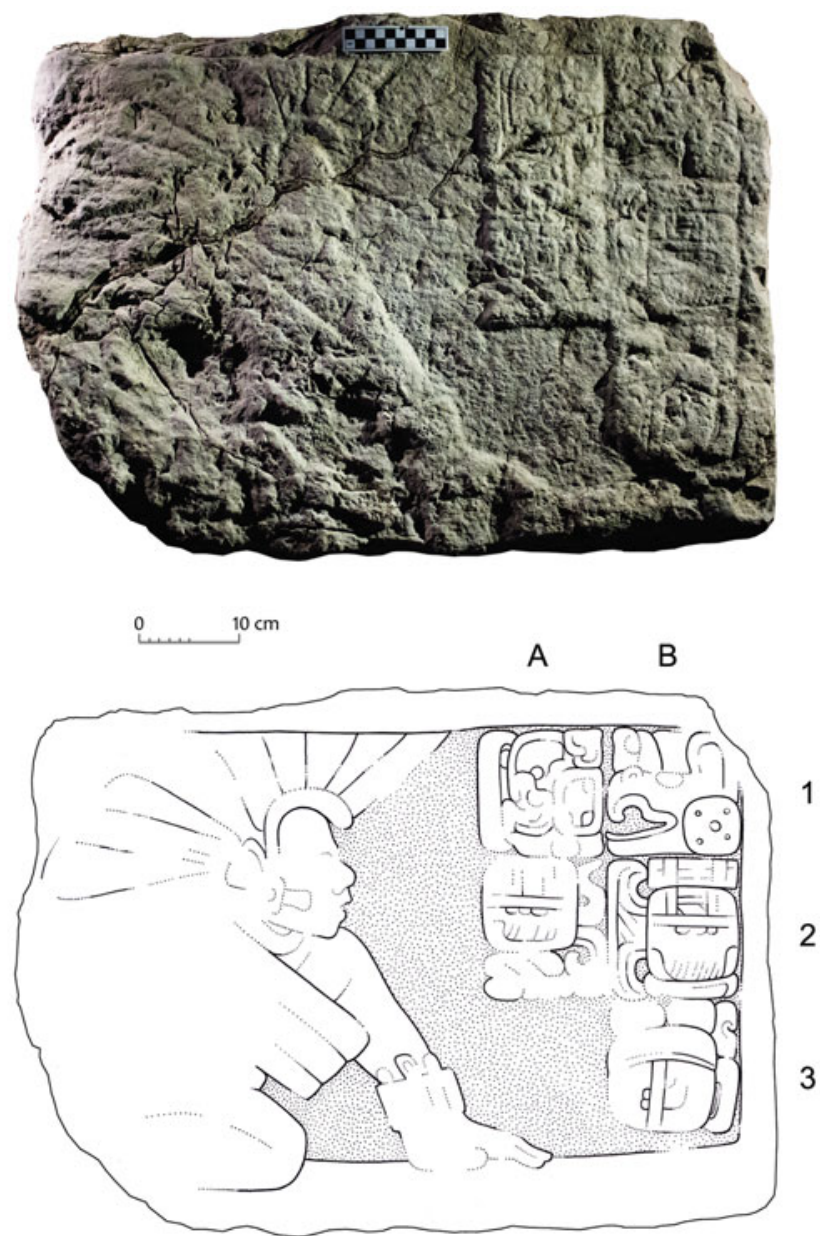

Figure 6. Monument 4, Tipan Chen Uitz, Belize (photograph and drawing by Christophe Helmke).

a title for historical individuals, although examples are known from Tikal and possibly Naj Tunich (see Jones \& Satterthwaite 1982: fig. 8a; MacLeod \& Stone 1995: 167, 178, 183).

Ballplayer panels usually depict local individuals squaring off against foreign exalted elites from distant sites. While we cannot be sure which of the two individuals represented on the panels is local and which is foreign, the features tying monument 4 to Naranjo may suggest that the depicted individual was from the latter site, while the monument 3 individual was possibly a local figure. A glyphic reference at Naranjo may support this conclusion, as discussed below.

\section{Broader significance}

The form and content of monuments 3 and 4 provide a basis for identifying specific actors within Tipan's political network. Similar panels are known for the sites of La Corona, Uxul, El Perú, Yaxchilan, Zapote Bobal, Dos Pilas, and farther afield at Tonina and Quirigua, 
among others (Graham 1982: 155-64; Miller \& Houston 1987; Houston 1993: fig. 3-22; Tunesi 2007; Crasborn et al. 2012; Stuart 2013; Grube \& Delvendahl 2014; Lee \& Piehl 2014: 95-98; Stuart et al. 2015) (Figure 7). Many of the sites are also known to have been vassals of the Snake-Head dynasty that had its seat of power at Calakmul during the Late Classic period (Martin 2005). A comparable ballplayer panel has recently been found at Calakmul proper, which dates stylistically to the start of the eighth century AD (Martin 2012: 160), thereby making it contemporaneous with the Tipan monuments.

Evidence of a possible connection with Calakmul, perhaps reflecting performances focused within specific architectural contexts (such as the ballcourt at Tipan), is not necessarily unexpected when considering the 'superpower' status of the Snake-Head dynasty and its far-reaching influence during the Late Classic, including at supra-regional centres such as Caracol to the south of Tipan (Martin \& Grube 2000: 88-95, 105-106). At Naranjo, stela 25 records a clear statement of overlordship when it relates that Tuun K'ab Hix, king of Calakmul, presided over the accession of Naranjo's incumbent ruler in AD 546 (Martin \& Grube 2000: 72, 104). Calakmul also politically eclipsed Tikal during the sixth century $\mathrm{AD}$, displacing its patronage and resulting in a shift of allegiances with former allies aligning themselves with Calakmul. Tipan's Middle Classic ceramics may provide evidence of the community's status as a client state of Tikal (Andres et al. 2014: 54-55). Following the defeat of Tikal by Calakmul and its allies in AD 562, Naranjo's influence increased, especially in this part of the Maya area (Martin \& Grube 2000: 74-81; Helmke $\&$ Awe 2012: 74-80). We previously suggested that the large monolithic panels that face the stair-side outsets at Tipan (and at its satellite sites of Yaxbe and Cahal Uitz $\mathrm{Na}$ ) represent a regional tradition originating in the Pasión area of Guatemala, perhaps introduced to this part of the lowlands by Lady Six Sky of Dos Pilas when she moved to Naranjo in AD 682 (Martin \& Grube 2000: 74-75; Andres et al. 2014). This intriguing possibility gains further support from Tipan monument 3; specifically, the mention to Waterscroll Ocelot on monument 3 may echo another in the eroded text of Naranjo stela 31. Here, an individual appearing to bear the same name is cited in connection with an event in $\mathrm{AD}$ 719 (see Graham 1978: 84). In addition, the name of the figure depicted on monument 4 , and the repetition of the same name on the fragmentary ballcourt sculpture at Naranjo, provides yet another link between these two sites. At present, we cannot be certain that the individuals mentioned at Tipan and at Naranjo are one and the same. Considering the rarity of the names, and the contemporaneity of the monuments, however, we find this conclusion compelling.

Finally, the existence of a possible hieroglyphic stair at Tipan may provide insight into the nature of this hypothesised relationship with Calakmul. The context of Tipan's ballplayer panels raises questions about their original position on structure A-1, although the scale and horizontal format of monuments 3 and 4 suggest that they certainly could have functioned as stair risers. Sites with hieroglyphic stairs often have ballplayer panels (see Boot 2011). The distribution of these sites seems far from coincidental, and probably represents the material imprint of greater socio-political networks of alliances and vassalage, also evidenced in the glyphic corpus (Figure 7). Thus, wide stretches of the lowlands to the east and west of Tikal exhibited either hieroglyphic stairs and/or ballplayer panels. This probably reflects the influence of the Snake-Head kingdom. Of particular interest here is a consideration of (C) Antiquity Publications Ltd, 2017 
Two Classic Maya ballplayer panels from Tipan Chen Uitz, Belize

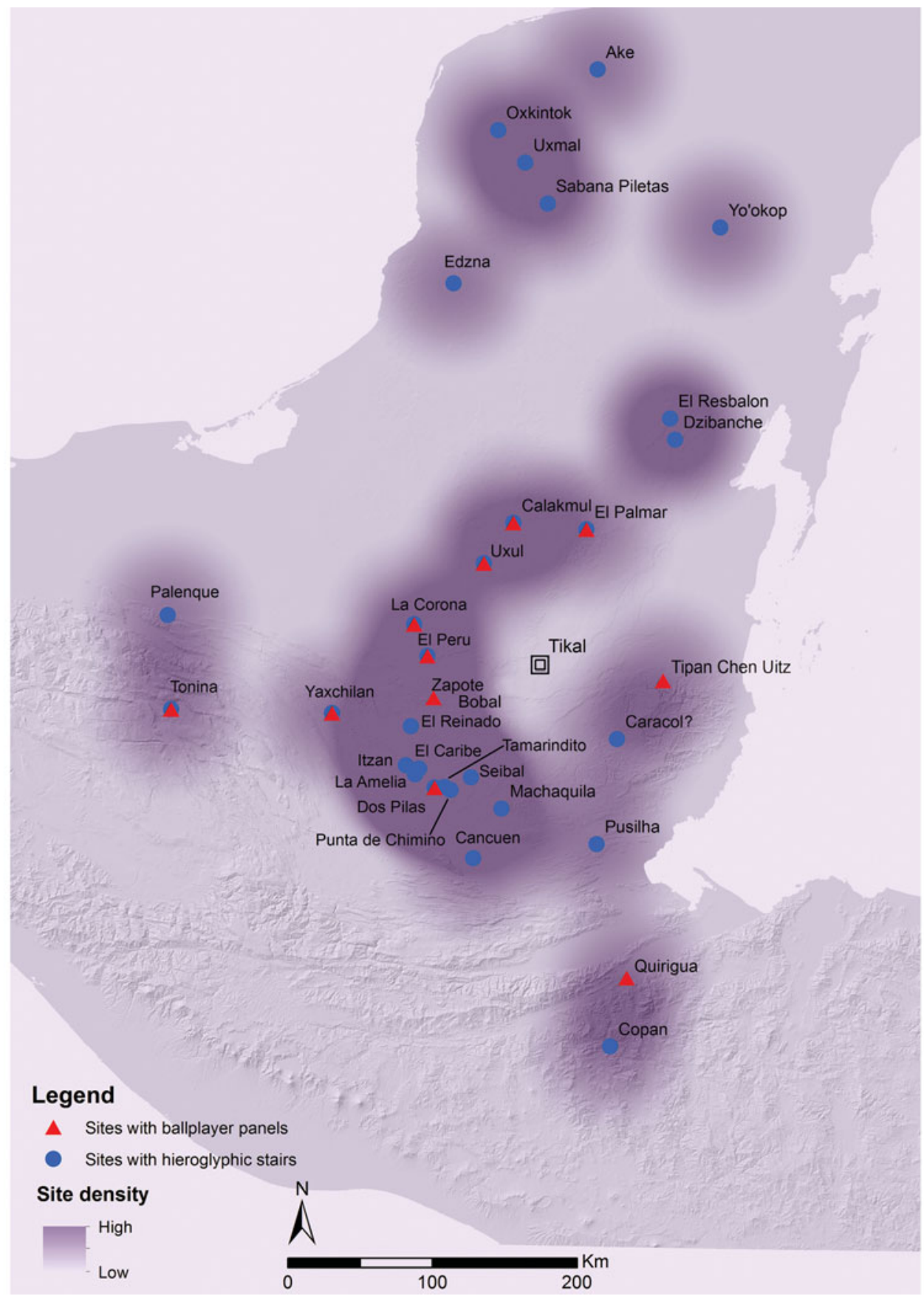

Figure 7. The distribution of archaeological sites in the Maya area with hieroglyphic stairs (blue dots) and the location of sites with ballplayer panels (red triangles). Site density is indicated by purple shading (map by Eva Jobbová). 
Calakmul's apparently variable levels of involvement in affairs of communities throughout the lowlands during the Late Classic (see Grube \& Delvendahl 2014). Calakmul kings clearly exerted their influence at locations as distant as Cancuen and Quirigua. Yet in contrast with patterns evident at other sites, the political involvement of the Snake-Head dynasty does not appear to have significantly affected the agendas and trajectories of these communities (Grube \& Delvendahl 2014: 93-94). Likewise, the absence of unequivocal evidence for Calakmul influence on Tipan's architecture and site layout suggests an indirect and less active role of Snake-Head kings in central Belize.

The far-reaching influence of Calakmul evident at Naranjo, and perhaps at Tipan, is significant relative to broader considerations of peer-polity relationships, client states and ancient interaction spheres (e.g. Renfrew \& Cherry 1986). When considered alongside portable objects, architectural markers, depictions of foreign emissaries and historical documentation of inter-community and/or inter-cultural interactions in such cases as Cahokia in mid-continental North America (Griffin 1993; Stoltman 2000), Teotihuacan in the Valley of Mexico (see papers in Braswell 2003), and Hellenistic Greece (Ma 2003), the ballplayer panels discussed here expand scholarly appreciation of the impressive range of expressions of these ancient interactions.

Investigations at Tipan have only recently begun, and direct references to Calakmul rulers in the site's hieroglyphic corpus are yet to be documented. Nevertheless, a conspicuous lack of stelae at Tipan, at least to date, combined with the presence of panels - together a hypothesised signature of Calakmul vassalage (Grube \& Delvendahl 2014: 93) — may reflect Tipan's membership in a sphere of interaction that was presided over by the Snake-Head kings. Although the current evidence does not support strongly hegemonic relations between Calakmul and Tipan, future investigations should yield finds that will clarify the place of Tipan in the networks of allegiances connecting centres in the central Maya lowlands.

\section{Acknowledgements}

We would like to thank the Belize Institute of Archaeology for granting us permission to conduct the reported research. This research has been supported and funded by a variety of institutions, including the University of Mississippi at Oxford, Indiana University-Purdue University Fort Wayne, Indiana University's New Frontiers in the Arts and Humanities programme, the University of Calgary, Michigan State University, and the Internationalisation Committee of the Institute of Cross-Cultural and Regional Studies, University of Copenhagen. We are grateful to the residents of Springfield and Armenia, Belize, for their support; and to David Hayles for granting us access to Tipan. Many thanks to Dmitri Beliaev, Guido Krempel, Felix Kupprat, Sebastián Matteo, Alexandre Tokovinine and Verónica Vázquez López for their help and comments on the hieroglyphic texts. Our gratitude also goes to Eva Jobbová, who kindly produced Figure 7 in ArcGIS. The excavation and recovery of monuments 3 and 4 would not have been possible without assistance from Franz Harder and Hugo Claro. Our thanks go to John Morris and Jaime Awe for encouraging our research in the Roaring Creek Works. Finally, we are grateful to the two anonymous reviewers for providing insightful feedback that has helped to strengthen this paper. Any shortcomings of fact or interpretation are ours alone.

\section{References}

Andres, C.R., G.D. Wrobel \& S.G. Morton. 2010. Tipan Chen Uitz ('Fortress Mountain Well'): a major 'new' Maya civic-ceremonial center in the Cayo District, central Belize. Mexicon 32: 88-94.
Andres, C.R., G.D. Wrobel, S.G. Morton \& J.J. GonzÁlez. 2011a. Insights into pre-Hispanic Maya power and status in the Caves Branch River Valley. Research Reports in Belizean Archaeology 8: 43-54.

(C) Antiquity Publications Ltd, 2017 
Andres, C.R., S.G. Morton, J.J. GonzÁlez \& G.D. Wrobel. 2011b. Causeways and sociopolitical integration in the Caves Branch Region, in C.R. Andres \& G.D. Wrobel (ed.) The Caves Branch Archaeological Survey Project: a report of the 2010 field season: $127-47$. Oxford (MS): Belize Archaeological Research and Education Foundation.

Andres, C.R., C. Helmke, S.G. Morton, G.D. Wrobel \& J.J. GonZÁlez. 2014. Contextualizing the glyphic texts of Tipan Chen Uitz, Cayo District, Belize. Latin American Antiquity 25: 46-64. https://doi.org/10.7183/1045-6635.25.1.46

Awe, J.J. (ed.). 1998. The Western Belize Regional Cave Project: a report of the 1997 field season (Department of Anthropology, Occasional Paper 1). Durham: University of New Hampshire.

- 1999. The Western Belize Regional Cave Project: a report of the 1998 field season (Department of Anthropology, Occasional Paper 2). Durham: University of New Hampshire.

Awe, J.J. \& C. Helmke. 2007. Fighting the inevitable: the Terminal Classic period of the Upper Roaring Creek Valley. Research Reports in Belizean Archaeology 4: 29-42.

Bíró, P. 2010. A new look at the inscription of Copan Altar K. The PARI Journal 11(2): 22-28.

Bоот, E. 2011. Maya sites with hieroglyphic stairways, a preliminary list. Maya News Updates, 4 May 2011. Available at: http://mayanewsupdates. blogspot.dk/2011/05/maya-news-updates-2011no_04.html (accessed 7 April 2017).

Braswell, G.E. (ed.). 2003. The Maya and Teotihuacan: reinterpreting Early Classic interaction. Austin: University of Texas Press.

Coe, M.D. 2003. Another look at the Maya ballgame, in D. Dominici, C. Orsini \& S. Venturoli (ed.) Il sacro e il paesaggio nell'America indigena: 197-204. Bologna: CLUEB.

Crasborn, J., E. Marroquín, F. Fahsen \& M.E. Vega. 2012. Un nuevo monumento en Quirigua: la banca y panel tallados de la Estructura 1B-14 del Grupo Este, in B. Arroyo, L. Paiz \& H. Mejía (ed.) XXV Simposio de Investigaciones Arqueológicas en Guatemala, 2011: 387-401. Guatemala City: Ministerio de Cultura y Deportes, IDEAH \& Asociación Tikal.

Graham, I. 1978. Corpus of Maya hieroglyphic inscriptions, volume 2, part 2: Naranjo, Chunhuitz, Xunantunich. Cambridge (MA): Peabody Museum of Archaeology and Ethnology, Harvard University.

- 1980. Corpus of Maya hieroglyphic inscriptions, volume 2, part 3: Ixkun, Ucanal, Ixtutz, Naranjo. Cambridge (MA): Peabody Museum of Archaeology and Ethnology, Harvard University.
- 1982. Corpus of Maya hieroglyphic inscriptions, volume 3, part 3: Yaxchilan. Cambridge (MA): Peabody Museum of Archaeology and Ethnology, Harvard University.

Griffin, J.B. 1993. Cahokia interaction with contemporary southeastern and eastern societies. Midcontinental Journal of Archaeology 18: 3-17.

Grube, N. 2004. La historia dinástica de Naranjo, Petén. Beiträge zur Allgemeinen und Vergleichenden Archäologie 24: 195-213.

Grube, N. \& K. Delvendahl. 2014. The monuments of the 8 Ajaw House: new evidence on the Calakmul-Uxul relationship, in C. Helmke \& F. Sachse (ed.) A celebration of the life and work of Pierre Robert Colas (Acta Mesoamericana 27): 75-95. Munich: Anton Saurwein.

Grube, N. \& W. Nahm. 1994. A census of Xibalba: a complete inventory of way characters on Maya ceramics, in J. Kerr (ed.) Maya vase book, volume 4: 686-715. New York: Kerr Associates.

Helmke, C. 2007. Classic Maya rubber balls in texts and imagery. Paper presented at 'The Classic Maya Ballgame' workshop, $12^{\text {th }}$ European Maya Conference, Geneva, 3-7 December 2007.

-2009 . Ancient Maya cave usage as attested in the glyphic corpus of the Maya lowlands and the caves of the Roaring Creek Valley, Belize. Unpublished $\mathrm{PhD}$ dissertation, University College London.

Helmke, C. \& C.R. Andres. 2015. Discovery and description of monument 2 at Tipan Chen Uitz, Belize. Mexicon 37: 112-17.

Helmke, C. \& J.J. Awe. 2012. Ancient Maya territorial organisation of central Belize: confluence of archaeological and epigraphic data. Contributions in New World Archaeology 4: 59-90.

Helmke, C. \& H. Kettunen. 2011. Where Atole abounds: Naranjo during the reign of K'ahk' Tiliw Chan Chahk. Cracow: Jagellonian University.

Helmke, C. \& J. Nielsen. 2009. Hidden identity \& power in ancient Mesoamerica: supernatural alter egos as personified diseases. Acta Americana 17(2): 49-98.

Helmke, C., J.J. Awe \& N. Grube. 2010. The carved monuments and inscriptions of Xunantunich, in L.J. LeCount \& J. Yaeger (ed.) Classic Maya provincial politics: Xunantunich and its hinterlands: 97-121. Tucson: University of Arizona Press.

Houston, S.D. 1993. Hieroglyphs and history at Dos Pilas: dynastic politics of the Classic Maya. Austin: University of Texas Press.

Houston, S.D. \& D. Stuart. 1989. The way glyph: evidence for co-essences among the Classic Maya. Research Reports on Ancient Maya Writing 30: 1-16. 


\section{Christopher R. Andres et al.}

Houston, S.D., H. Escobedo, C. Golden, A. Scherer, R. Vásquez, A.L. Arroyave, F. QuiroA \& J.C. Meléndez. 2006. La Técnica and El Kinel: mounds and a monument upriver from Yaxchilan. Mexicon 28: 87-93.

Jones, C. \& L. SATTerTHWAITE. 1982. The monuments and inscriptions of Tikal: the carved monuments (Tikal Report 33A). Philadelphia: University of Pennsylvania Museum.

Kerr, J. (ed.). 1992. The Maya vase book, volume 3. New York: Kerr Associates.

Lee, D.F. \& J.C. PieHl. 2014. Ritual and remembrance at the Northwest Palace Complex, El Perú-Waka', in O.C. Navarro-Farr \& M. Rich (ed.) Archaeology at El Peru-Waka': ancient Maya performances of ritual, memory, and power: 85-101. Tucson: University of Arizona Press.

MA, J. 2003. Peer polity interaction in the Hellenistic age. Past and Present 180(1): 9-39. https://doi.org/10.1093/past/180.1.9

MacLeod, B. \& A.J. Stone. 1995. The hieroglyphic inscriptions of Naj Tunich, in A.J. Stone (ed.) Images from the underworld: Naj Tunich and the tradition of Maya cave painting: 155-84. Austin: University of Texas Press.

Martin, S. 2005. Of snakes and bats: shifting identities at Calakmul. The PARI Journal 6(2): 5-13.

- 2012. Escritura, in R. Martínez Vera (ed.) Calakmul. Patrimonio de la humanidad: 156-75. México, D.F.: Grupo Azabache.

Martin, S. \& N. Grube. 2000. Chronicle of the Maya kings and queens. London: Thames \& Hudson.

Martin, S. \& J. Skidmore. 2012. Exploring the 584286 correlation between the Maya and European calendars. The PARI Journal 13(2): 3-16.

Miller, M.E. \& S.D. Houston. 1987. The Classic Maya ballgame and its architectural setting: a study in relations between text and image. RES 14: 46-65.

https://doi.org/10.1086/resv14n1ms20166774

Morton, S.G. 2015. Pahn-Ti-Pan: the rise and fall of complex socio-political and economic systems as attested in subterranean site contexts of central Belize, C.A. Unpublished PhD dissertation, University of Calgary.

Normark, J. 2009. Emergent subjectivity and defacement of Maya art. Archaeological Haecceities, 17 November 2009. Available at: https:// haecceities.wordpress.com/2009/11/17/emergentsubjectivity-and-defacement-of-maya-art/ (accessed 7 April 2017).
Renfrew, C. \& J.F. Cherry (ed.). 1986. Peer polity interaction and socio-political change. Cambridge: Cambridge University Press.

SChele, L. 1980. Maya glyphs: the verbs. Austin: University of Texas Press.

Schele, L. \& M.E. Miller. 1986. The blood of kings: dynasty and ritual in Maya art. Fort Worth (TX): Kimbell Art Museum.

Stoltman, J.B. 2000. A reconsideration of the cultural processes linking Cahokia to its northern hinterlands during the period A.D. 1000-1200, in S.R. Ahler (ed.) Mounds, Modoc, and Mesoamerica: papers in honor of Melvin L. Fowler (Illinois State Museum Scientific Papers 28): 439-67. Springfield: Illinois State Museum.

Stone, A. \& M. Zender. 2011. Reading Maya art: a hieroglyphic guide to ancient Maya painting and sculpture. London: Thames \& Hudson.

Stuart, D. 2005. The inscriptions from Temple XIX at Palenque: a commentary. San Francisco (CA): Pre-Columbian Art Research Institute.

- 2013. Tonina's curious ballgame. Maya Decipherment, June 11 2013. Available at: https://decipherment. wordpress.com/2013/06/11/report-toninascurious-ballgame/ (accessed 7 April 2017).

Stuart, D. \& S.D. Houston. 1994. Classic Maya place names. Washington, D.C.: Dumbarton Oaks Research Library and Collection.

Stuart, D., M.A. Canuto \& T. Barrientos Q. 2015. The nomenclature of La Corona sculpture. $\mathrm{La}$ Corona Notes 1(2): 1-9.

Tunesi, R. 2007. A new monument naming Wamaaw K'awiil of Calakmul. The PARI Journal 8(2): 13-19.

Wrobel, G.D., C.R. Andres, S.G. Morton, R. Shelton, A. Michael \& C. Helmke. 2012. Ritual landscapes of the Caves Branch River Valley. Research Reports in Belizean Archaeology 9: 233-44.

Wrobel, G.D., R. Shelton, S.G. Morton, J. Lynch \& C. Andres. 2013. The view of Maya mortuary cave ritual from Overlook Rockshelter (OVR), Caves Branch River Valley, central Belize. Journal of Cave and Karst Studies 75: 126-35. https://doi.org/10.4311/2011AN0233

Zender, M. 2004. Glyphs for 'handspan' and 'strike' in Classic Maya ballgame texts. The PARI Journal 4(4): 1-9.

Received: 2 June 2016; Accepted: 18 July 2016; Revised: 1 August 2016

(C) Antiquity Publications Ltd, 2017 